\title{
Urban morphology and urban fragmentation in Macau, China: island city development in the Pearl River Delta megacity region
}

\author{
Ni Sheng \\ School of Business, Macau University of Science and Technology, Macau, China \\ nis@must.edu.mo
}

U Wa Tang

Macao Institute of Urban Development and Environmental Management, Macau, China uwtang@gmail.com

and

\author{
Adam Grydehøj \\ Island Dynamics, Denmark \\ Institute of Island Studies, University of Prince Edward Island, Canada \\ agrydehoj@islanddynamics.org
}

\begin{abstract}
The island city of Macau, part of China's Pearl River Delta megacity region, has undergone urban fragmentation, occasioning transport problems and environmental inequalities as well as conditioning future urban development. Land scarcity associated with island spatiality encourages dense and incremental urban expansion, facilitated by coastal land reclamation, causing spatiotemporal urban fragmentation. The Macau Peninsula, formerly a hilly island, has expanded and become increasingly connected to the mainland over the centuries. Macau faces critical challenges regarding traffic congestion, environmental pollution, and lack of space for housing and other urban functions. As Macau becomes increasingly integrated into the Pearl River Delta megacity region, particularly through the construction of the Hong Kong-Zhuhai-Macau Bridge, the island city's urban planning strategy uses land reclamation to create new urban zones. This may produce new urban space for social and economic development yet risks further urban fragmentation. We argue that spatially and historically sensitive geographical understandings of island city development and urban morphology are necessary for understanding Chinese urbanisation and coastal cities.
\end{abstract}

Keywords: China, island cities, Macau, Pearl River Delta megacity region, urban fragmentation, urban morphology

https://doi.org/10.24043/isj.25

(C) 2017 - Institute of Island Studies, University of Prince Edward Island, Canada.

\section{Introduction}

In recent decades, urban studies has become increasingly concerned with urban fragmentation, referring to the morphological differentiation of pieces of urban land and their dispersal within urban space (Carsjens \& van Lier, 2002; Wei \& Zhang, 2012). Graham and Marvin (2001) warn of the dangers of 'splintering urbanism', and Bremner (2017) shows how archipelago spatiality can encourage social, economic, and legal fragmentation. Harvey (2001, p. 350) has highlighted the paradox of urban fragmentation in the age of mobility: 
On the one hand we witness the greater fragmentation of the urban social space into neighbourhoods, communities, and a multitude of street corner societies, while on the other telecommuting and rapid transport make nonsense of some concept of the city as a tightly-walled physical unit or even a coherently organized administrative domain.

Harvey (2001) emphasises American cities' simultaneous expansion and deconcentration, yet the combination of enhanced fragmentation and enhanced mobility also occurs within dense cities and networks of cities. The current paper explores geographical causes and environmental effects of urban fragmentation within the small and densely populated city of Macau. Macau itself is integrating into China's emerging Pearl River Delta megacity region, perhaps the pinnacle of today's move toward large-scale, polycentric, designed urban systems of connected fragmentation (Bie et al., 2015).

As China continues undergoing explosive urbanisation, research into the fragmentation of Chinese cities has been gathering pace. In the context of rapidly expanding cities that attract migrants and swallow up rural villages and industrial units, He and Qian (2016, p. 10) warn that:

The emergence of enclave spaces, increasing residential mobility, and socio-economic inequality, coupled with the increasing commodification of urban space, has resulted in visible socio-spatial segregation, fragmentation and division. [...] Featuring a high degree of heterogeneity within and between different types of neighbourhoods, enclave urbanism in China entails a complex relationship between urban form and social fabric.

Most research into urban fragmentation in China has focused on megacities such as Beijing, Shanghai, and Guangzhou (Chen et al., 2014; Gao et al., 2014; Kuang et al., 2014; Li et al., 2013; Schneider et al., 2005; You, 2016a, 2016b; Yu \& Ng, 2007; Yue et al., 2013) and key regions such as the Beijing-Tianjin-Hebei region and the Pearl River Delta as a whole (Lin, 2001; Tan et al., 2005; Yao \& Liu, 1995). Urban fragmentation in China's island cities per se has not been a focus of study, with just a few exceptions (e.g., Su, 2017; Hong, 2017). Such research is crucial, however, not just because the spatial characteristics of island cities are associated with a coupling of high urban density and slow spatial expansion (Grydehøj, 2015a) — which renders impossible many expansion-oriented urban solutions-but also because of under-recognition of the role such island cities play in wider networks of coastal cities in China and elsewhere in Asia. That is, the American and European foundations of much research into urban fragmentation may be only problematically applicable to Chinese island cities and the networks of which they form a part. We argue that spatially and historically sensitive geographical understandings of island city development are necessary if we are to understand Chinese urbanisation more broadly.

Grydehøj (2015a) posits that the benefits to island spatiality encourage dense urbanisation but also encourage land reclamation, which can cause island and mainland to merge, rendering the islandness of island cities invisible. It is thus that the island origins of many urban centres in the region are no longer evident. Yet cities in general, and perhaps island cities in particular, are characterised by "a confluence of spatiotemporal factors (whether human or machine) that abidingly guide development in interplay with further external inputs" (Grydehøj, 2014a, p. 207). A city's island spatiality conditions certain developmental choices, which in turn condition future choices, even after the city has merged with the mainland and ceased to be self-evidently an island.

The island city of Macau is a prime example of this process. Like many cities, Macau faces critical challenges as a result of traffic congestion and problematic urban renewal, which in turn hinder social, economic, and environmental development. Macua's archipelagic status influences development in ways that have been poorly understood by administrators and scholars: incremental land reclamation has led to spatiotemporal urban fragmentation. This paper elaborates upon Macau's historical development and analyses its urban fragmentation and the impacts this has had on transport and the urban environment over time, drawing upon data presented in previous studies (Sheng \& Tang, 2011; Sheng \& Tang 2013; Tang \& Wang, 2007). 


\section{Macau and the Pearl River Delta megacity region}

Macau (Figure 1), located in the southwest corner of the Pearl River Delta, is $30.4 \mathrm{~km}^{2}$ in total and comprises the Macau Peninsula $\left(9.3 \mathrm{~km}^{2}\right)$, Taipa Island $\left(7.6 \mathrm{~km}^{2}\right)$, Coloane Island $\left(7.6 \mathrm{~km}^{2}\right)$, and the Cotai reclamation zone $\left(5.9 \mathrm{~km}^{2}\right)$ (DSEC, 2016).

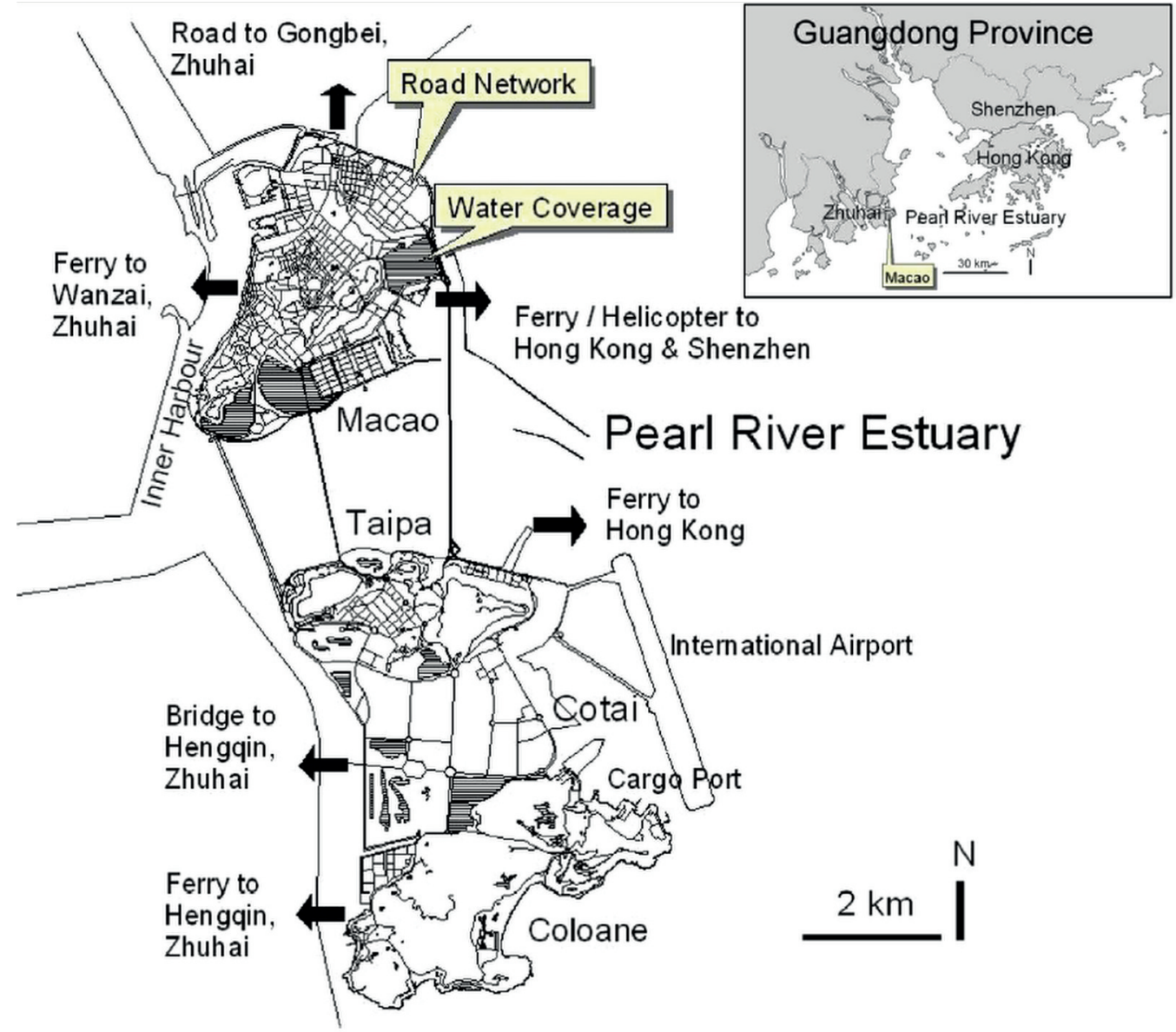

Figure 1: The archipelago of Macau. (C) Tang \& Sheng, 2009)

By some measures, the Pearl River Delta is the world's most-populous urban conglomeration (Van Mead, 2015): a 'megacity region' consisting of numerous major cities linked by a complex infrastructural network of transport, utilities, and IT connections (Time Out Hong Kong, 2016). The most spectacular element in this infrastructure network is the Hong Kong-Zhuhai-Macau Bridge, which (when complete) will provide a fixed link for automobile traffic between the island cities at the extreme southeast and southwest of the Pearl River Delta.

There has been much debate within island studies on the effects that fixed transport links and other connective infrastructure have on island cultures, populations, and economies. There is evidence to support various contradictory conclusions regarding the extent to which island-to-mainland and island-to-island connective infrastructure is harmful or beneficial to islanders and their conceptions of living on islands (Baldacchino, 2007; Baldacchino \& Pleijel, 2010; Brophy, 2017; Gillis, 2004, p. 154; Raadik Cottrell, 2017). Regardless of the lessons from remote and sparsely populated island communities, however, more knowledge is needed concerning the effects of fixed links on island cities (Leung et al., 2017). As we shall see below, the Macau Peninsula has long been connected to mainland China, yet its spatial development has continued to be influenced by recognisably insular factors. It is possible that the agglomeration benefits arising from dense urbanism in island spaces with excellent water transport accessibility 
(Grydehøj, 2015a), which historically nurtured island cities early in their development, may be further strengthened down the line by fixed transport links for trains and automobiles.

As Simpson (2014, p. 830) notes, the Pearl River Delta megacity region is "a discontinuous urban form comprised of a number of enclave zones, each with a particular function." This proliferation of enclaves and functional distinctions is linked to the region's river delta geography, with island and archipelago spatialities encouraging the development of important trading posts in Guangzhou (capital of Guangdong Province), Hong Kong (a former British colony), and Macau (a former Portuguese colony), which in turn encouraged the urbanisation of nearby islands and coastal zones such as Shenzhen and Zhuhai (Special Economic Zones adjacent to Hong Kong and Macau respectively) as well as Dongguan, Zhongshan, and Jiangmen. Island cities of this sort are networked by nature and design: remoteness, inaccessibility, and lack of connectivity would occasion the demise of these places' distinctive urban island lifestyles and practices, not accentuate their islandness.

\section{Historical development of Macau: from tombolo to peninsula}

Macau's modern history can be divided into two periods, coinciding with the respective economic booms of Portugal and China (Sheng \& Tang, 2015). The first period began in 1557, when the Chinese Emperor gave tacit approval for Portuguese occupation of a portion of what is today the Macau Peninsula. The Portuguese subsequently established a Western trade monopoly with China, and Macau soon became the major regional economic centre for Europeans trading with Asian states. The Portuguese gradually expanded their administration across the whole of the Macau Peninsula and eventually occupied three additional adjacent islands, i.e., Taipa, Coloane, and Ilha Verde.

The second period began on 20 December 1999, when Macau ceased to be a Portuguese colony and became a Special Administrative Region of China. Macau is now the only city in China to permit gambling and, like Hong Kong across the Pearl River Delta, functions under the 'one country, two systems' model of differential governance. Macau's gambling revenues in 2013 reached US $\$ 45$ billion, seven times greater than those of Las Vegas (Riley, 2014). As far as culture is concerned, the Historic Center of Macao was awarded 'World Cultural Heritage' status by the United Nations Educational, Scientific and Cultural Organization (UNESCO), which cited the "dramatic mixing of eastern and western buildings in this jewel" (UNESCO, 2005).

In order to understand how Macau reached its present form and to identify the hidden forces that island spatiality exerts on urban development, it is first necessary to study the history of Macau's landscape. With a few exceptions (e.g., Grydehøj, 2015b; Li, 2016; Zadori, 2016), Macau's island or archipelago status has rarely been remarked upon, much less used as an analytical perspective, in the literature. The Macau Peninsula was not always a peninsula but was once an isolated island, which only gradually became connected to mainland China as a tombolo or land-tied island (i.e., an island attached to the mainland by a narrow strip of land).

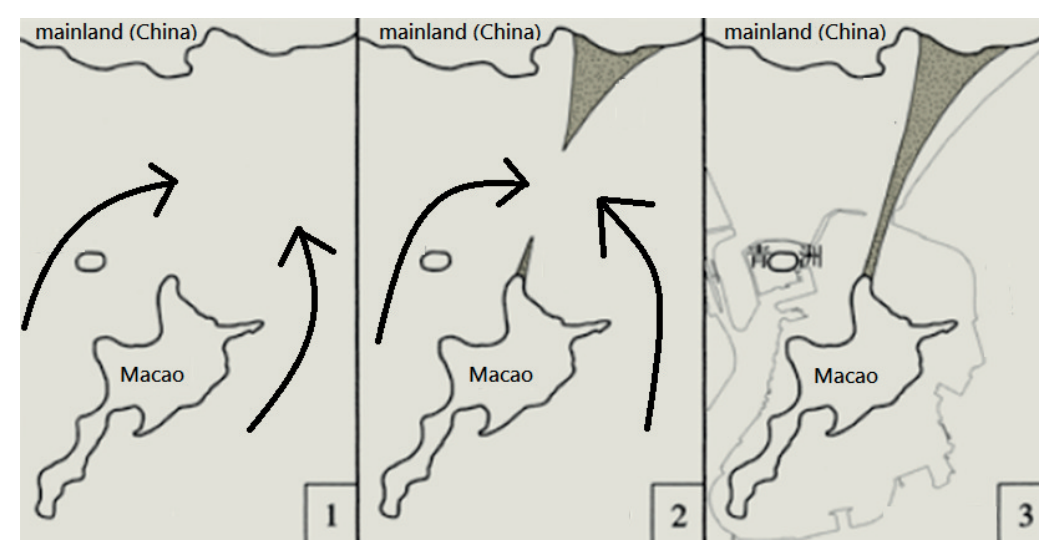

Figure 2: Tombolo formation and land reclamation in Macau. (Modified from (C Vong, 2009). 
As Miyahara et al. (2014) describe, a tombolo may form when waves sweep sediment along both coasts of a near-shore island, meeting at the back of the island and depositing material there. Two sand spits then gradually form on the opposite banks, and when these two spits meet and join, the isolated island becomes tied to the mainland (Figure 2). Numerous authors have noted that presqu'iles ('almost islands') and peninsulas can have effects reminiscent of and be subject to similar processes as islands (Hayward, 2016; Hayward \& Fleury, 2016; Johnson \& Kuwahara, 2016; Mendas, 2016).

When Portuguese colonialists settled in the south of Macau in 1557, the landscape was primarily hilly. The Chinese village of Mongha had been established at the southern end of the tombolo (i.e., the northern end of the then-island), where most of the flat and cultivated land was located. Thereafter, natural sedimentation and artificial land reclamation occurred successively on both sides of the tombolo and around the rest of the coast to support urban growth. The narrow tombolo disappeared, and the island of Macau became a peninsula. In 1561, the island of Macau had a population of just 500. By March 2015, the mere $9.3 \mathrm{~km}^{2}$ of the Macau Peninsula held around 520,000 residents (DSEC, 2016). The Macau Peninsula's population density of 55,900 inhabitants $/ \mathrm{km}^{2}$ is nearly 3.5 times that of Hong Kong Island. Most of the land area of the Macau Peninsula is composed of artificial 'reclaimed' land (Figure 3, bottom right).

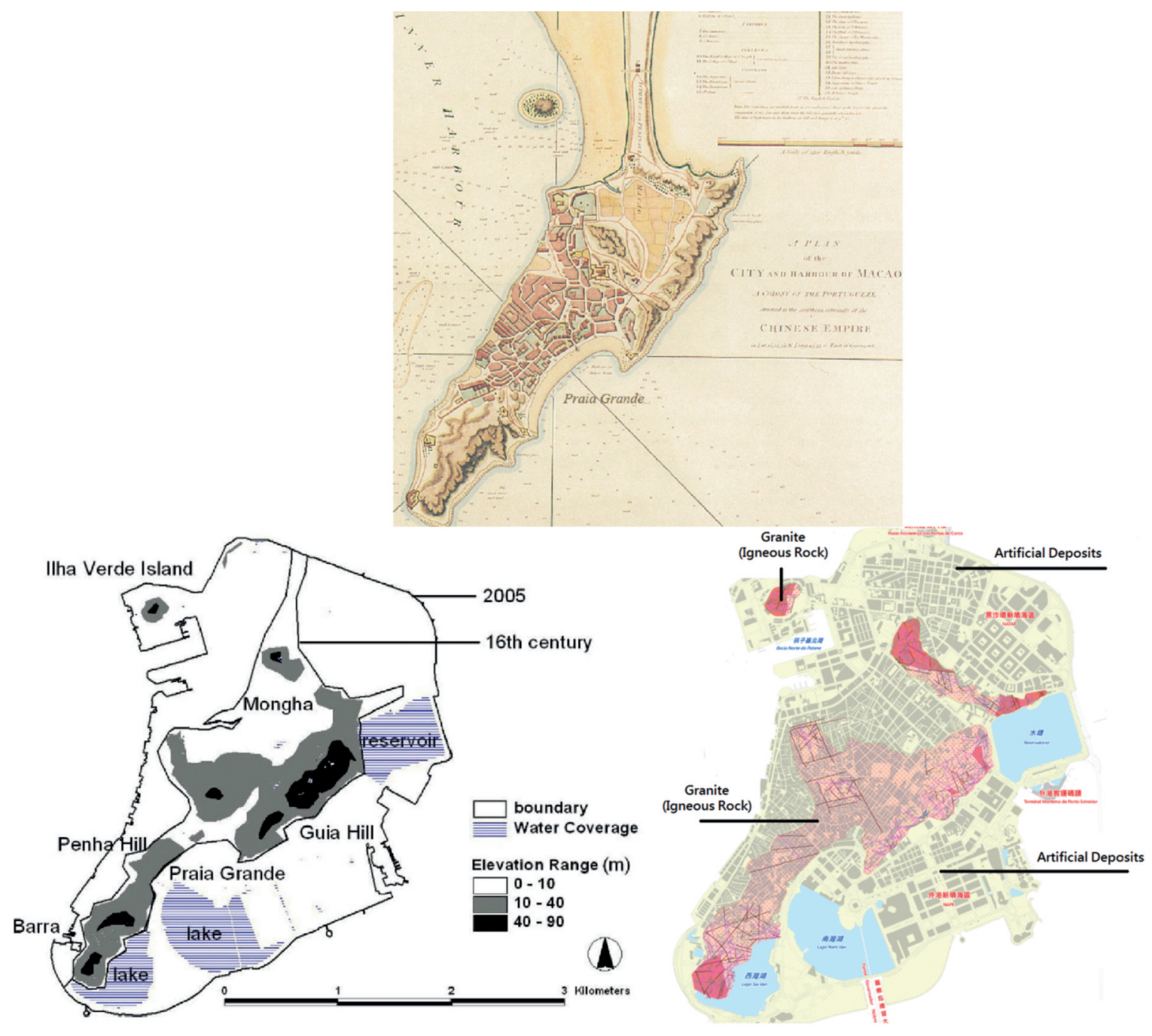

Figure 3: Top: Macau as a tombolo in 1796 (C) Câmara Municipal de Macau Provisória, 2001); Bottom left: Significant coastline change (C) Tang \& Sheng, 2009); Bottom right: Geological map (C Macau Government). 


\section{Urban fragmentation and environmental problems}

Previously published data by the authors (Sheng \& Tang, 2011; Sheng \& Tang 2013; Tang \& Wang, 2007) inform the following analyses of traffic, pollution levels, and road and building ratios with regard to the Macau Peninsula's spatial development.

Urban growth on the Macau Peninsula can be divided into four phases: 1557-1846, 1846-1912, 1912-1957, and 1957-present. These phases of expansion resulted in distinct urban growth areas, here designated as Urban Fragments 1-4 (Figure 4). The Macau Peninsula's urban fragments are very small, each covering less than $3 \mathrm{~km}^{2}$. Although Macau's economic and demographic development has been continual and often rapid since 1557, urban growth has been modest in terms of land cover due to Macau's special political and geographical conditions. Politically, the Portuguese acquired only a small piece of land (Urban Fragment 1) as a trading station in the early stages of the colony. The remainder of the peninsula (Urban Fragment 2 and about half of Urban Fragment 3) comprised Chinese farmland and villages but was gradually occupied by the Portuguese for urban development, becoming virtually absorbed into the Portuguese colony by the 20th Century. Thereafter, land reclamation (the rest of Urban Fragment 3 and all of Urban Fragment 4) became the only means of providing for further growth. The rate of urban growth through coastal land reclamation was nevertheless slow, for both economic and political reasons. Coastal land reclamation was politically sensitive since China never regarded Portugal's rights in Macau as extending into the territory's surrounding marine areas (Tang \& Sheng, 2009). As a result, the four centuries of Portuguese rule saw only relatively modest land reclamation projects.

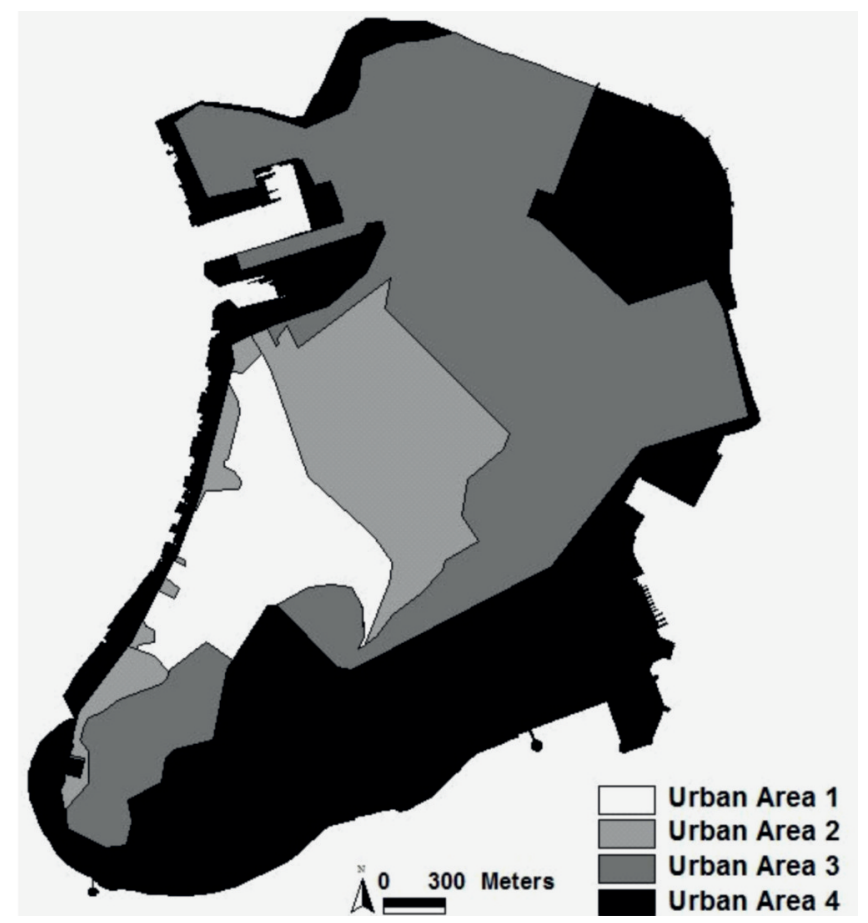

Figure 4: Small urban fragments on the Macau Peninsula. (C) Sheng \& Tang, 2017)

As they did in other colonial trading stations (often islands) in Africa and India (e.g., Steyn, 2015), the Portuguese in Macau began constructing defensive walls around the settlement at an early stage, starting in 1569. This clashed with the policy of China's Ming government, which forbade the construction of city walls, and Macau's walls were demolished on several occasions as a result. With the emergence of Dutch maritime power in the region in 1612, Portuguese representatives from Macau travelled to Canton (today's Guangzhou), the capital of Guangdong Province, to argue that fortifications were required to defend Macau against Dutch incursion 
(Garrett, 2010). Especially after the Portuguese soldiers and missionaries successfully repelled a Dutch invasion in 1622, the Portuguese found an excuse to construct city walls and forts around their settlement, making Macau a tightly guarded place. The section of the old city walls that remains today has been inscribed as part of the UNESCO Historic Center of Macao.

The city could only be entered through a small number of arched gateways in the city walls. The Portuguese colonialists lived within this confined area for over 200 years (1557-1794). This is the only fragment in Macau today with squares, cobbled streets, and alleyways possessing an intimate, human and cosy scale, reflecting the urban landscape of late-Medieval Portugal (Guillén-Nuñez, 2001). Buildings cover $71 \%$ of this urban area, road space $8 \%$, green space $2 \%$, and water $<1 \%$ (Sheng \& Tang, 2011). Similar to the historic centre of Lisbon, Urban Fragment 1 possesses a compact morphology, and the road network has a complex non-rectilinear pattern, which was originally designed for pedestrian and human-powered transport such as litters and sedan chairs. $65.8 \%$ of the roads in this historic urban centre are less than $10 \mathrm{~m}$ wide (Sheng \& Tang, 2011).

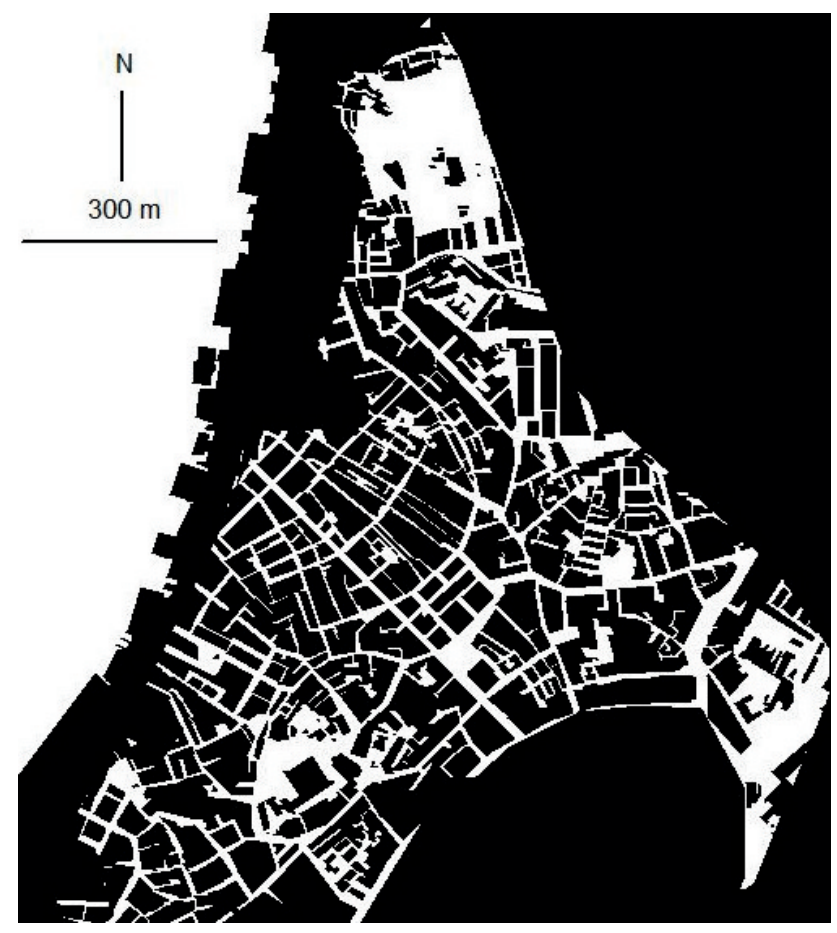

Figure 5: Historic centre of Macau. (C) Sheng \& Tang, 2017)

The complex curvature of the road network and the high percentage of narrow roads limit traffic speed, traffic capacity, and parking capacity in this urban fragment. Traffic volumes on most roads in Urban Fragment 1 are very low (200-400 vehicles/hour) compared with those in other urban fragments (1500-3000 vehicles/hour during evening rush hour). The reason for this is that drivers lack motivation to drive vehicles into the area and prefer to walk or use public transport instead. As a result, about $65 \%$ of traffic noise levels along the major pedestrian sidewalks in this area meet the National Standard of $70 \mathrm{~dB}(\mathrm{~A})$ (Sheng \& Tang, 2011). However, the large street canyon effect in the historic urban fragment decreases dilution of air pollution from ground-based traffic emission sources. The old town's canyon geometry can be defined by the ratio $\mathrm{H} / \mathrm{W}$, where $\mathrm{H}$ is the height of the canyon walls (buildings) and $\mathrm{W}$ is the canyon width (road width). Urban Fragment 1 has been found to have the city's highest H/W (1.9), i.e., on average, the building height is almost twice the width of the road. Thus, although traffic volumes are much lower than those in other urban fragments, concentrations of air pollutants are not significantly lower (Tang \& Wang, 2007). Particularly during evening rush hour, with a northerly wind direction (sector $0-20^{\circ}$ ), two UNESCO world heritage monuments in Urban Fragment 1 
(the Leal Senado building and the Cathedral) have been measured as exposed to excessive nitrogen dioxide concentrations of 135.9 and $121.1 \mathrm{lg} / \mathrm{m}^{3}$ respectively (Sheng \& Tang, 2013).

In the next phase of Macau's development (1846-1912), the city expanded and underwent morphological change. This period coincided with wider European experiments with the association between connective infrastructure, urban expansion, and social control. For example, GeorgesEugene Haussmann's 1853 street plan for Paris involves twelve boulevards radiating out from the Arc de Triomphe. This street plan represented an early attempt to modernise Paris' historic centre, which was dominated by crowded, unhealthy, and dangerous Medieval neighborhoods. Some researchers suggest that Haussmann's boulevards were also designed to make it easier for the military to maneuver and suppress armed insurrection (e.g., Graham, 2011, p. XVII).

Macau adopted a similar urban plan, with the construction of squares with boulevards radiating out in different directions across newly occupied areas, i.e., the rural areas, Chinese villages, and farmlands of Urban Fragment 2. In 1846, four years after the Opium War (1839-1842) and at the nadir of the Chinese state's power, the dynamic Portuguese military officer João Maria Ferreira do Amaral was appointed the 79'h Governor of Macau. During his three-year tenure as governor, he started implementing a series of policies to aggressively entrench Portugal's colonial authority over the territory and made a plan to gradually occupy all seven of the Chinese villages to the north of the Portuguese settlement on the Macau Peninsula as well as the three nearby islands of Taipa, Coloane, and Ilha Verde. The colonial occupation of the peninsula and islands was complete by the 1880s, when the two largest Chinese villages-Longtian and Mongha - on the northern half of the Macau Peninsula were fully occupied and administered by the Portuguese. The Portuguese adopted an urban plan that involved the construction of squares along the northern city wall, from which boulevards reached out toward the coasts. Bearing in mind that the military centre was located within the northern city wall, these boulevards assisted the Portuguese military in accessing the entirety of the peninsula.

Urban Fragment 2's radiating road network leads to higher traffic accessibility than Urban Fragment 1's curved road network. The proportion of 10-20 m wide roads in Urban Fragment 2 (40.6\%) is double that in Urban Fragment 1, allowing for higher traffic capacity, accessibility, and volumes. Over 50\% of Urban Fragment 2's roads have traffic volumes above 1500 vehicles/hour in evening rush hour. Only about 50\% of traffic noise levels along the major pedestrian sidewalks meet the National Standard of $70 \mathrm{~dB}(\mathrm{~A})$ (Sheng \& Tang, 2011). Similar to Urban Fragment 1, concentrations of air pollutants are high due to the high H/W of 1.6 (Tang \& Wang, 2007).

Urban Fragment 3 has been developed since 1912 and reflects modern urban design, which reserves more land for social welfare, industrial, and transportation uses. Water coverage has increased as a result of the construction of a reservoir for fresh water supply, an important resource in an island enclave. The road network has a modern rectilinear grid pattern. The proportion of roads less than $20 \mathrm{~m}$ wide decreases to $65.5 \%$, while that of roads $20-30 \mathrm{~m}$ wide increases to $23.2 \%$. As a result of infill development of high-rise buildings, only $67.1 \%$ of the fragment's buildings are lower than $30 \mathrm{~m}$, whereas the proportion of those with a height of 40-80 $\mathrm{m}$ has increased. With high traffic volumes on most roads, Urban Fragment 3 has the highest average traffic noise among the four urban fragments. Only about $19 \%$ of traffic noise levels along the major pedestrian sidewalks meet the National Standard of $70 \mathrm{~dB}(\mathrm{~A})$ (Sheng \& Tang, 2011).

A new wave of coastal land reclamation since 1957 has led to the development of Urban Fragment 4, reflecting the most recent trend of cluster development, which is less dense than the other urban forms and has the lowest building lot space and the highest road space, green space, water coverage, and land consumption per capita. The proportion of high-rise buildings 50-60 $\mathrm{m}$ in height increases to $39.5 \%$ to maintain high gross densities. The proportion of roads $20-30$ $\mathrm{m}$ wide increases significantly to $67.7 \%$ to serve the increasing demands of vehicular transport. A large rectangular grid pattern has been adopted to allow for wider roads and larger building blocks. Traffic congestion has been reduced through the adoption of additional wide roads and a lower density of intersections in the road network design. As a result, the average traffic noise 
is $69.3 \mathrm{~dB}(\mathrm{~A})$, which is the lowest of the four urban fragments. The percentage of traffic noise levels along the major pedestrian sidewalks meeting the National Standard of $70 \mathrm{~dB}(\mathrm{~A})$ is about 51\% (Sheng \& Tang, 2011). The average H/W in Urban Fragments 3 and 4 are around 1.0-1.2. This lower H/W leads to increased dilution of air pollutants from ground-based traffic emission sources (Tang \& Wang, 2007).

Since land is among the most precious resources for island cities, urban growth in island cities is frequently accompanied by massive land reclamation along the coasts-sometimes occasioning social problems and inequalities (Grydehøj, 2015b). Macau's urban and economic growth have come at the cost of the peninsula's former bays, which have been filled in to create new land while two large artificial lakes have since been created in the southwest coastal reclamation projects. These estuarine lakes aim to retain, if not quite fully preserve, the historic coastal landscape of the old Praia Grande bay, which provides a view of Penha Church, the oldest western church in Asia and part of Macau's world heritage, atop Penha Hill (Tang \& Sheng, 2009).

Macau's historically contingent growth has led to the development of highly distinct urban fragments, which has occasioned spatial inequalities in environmental health. Macau's island status not only drove its selection as the site for a Portuguese trading port but has since significantly influenced the manner in which the city has undergone incremental expansion, with successive phases of land reclamation serving in particular to create spatial divisions among various urban functions (Grydehøj, 2015b). For all its explosive population growth, Macau can escape neither its history nor its islandness.

\section{Future urban fragments}

Over the next two decades, Macau will enter a new phase in its history with the implementation of an ambitious land reclamation program that will add more than $12 \%$ to the territory's land area and create five new districts: Urban Zones A, B, C, D, and E (Figure 6). Urban Zones A and B are in the northeast and southeast of the Macau Peninsula respectively, while Urban Zones $\mathrm{C}$, $\mathrm{D}$, and $\mathrm{E}$ are on the north coast of Taipa.

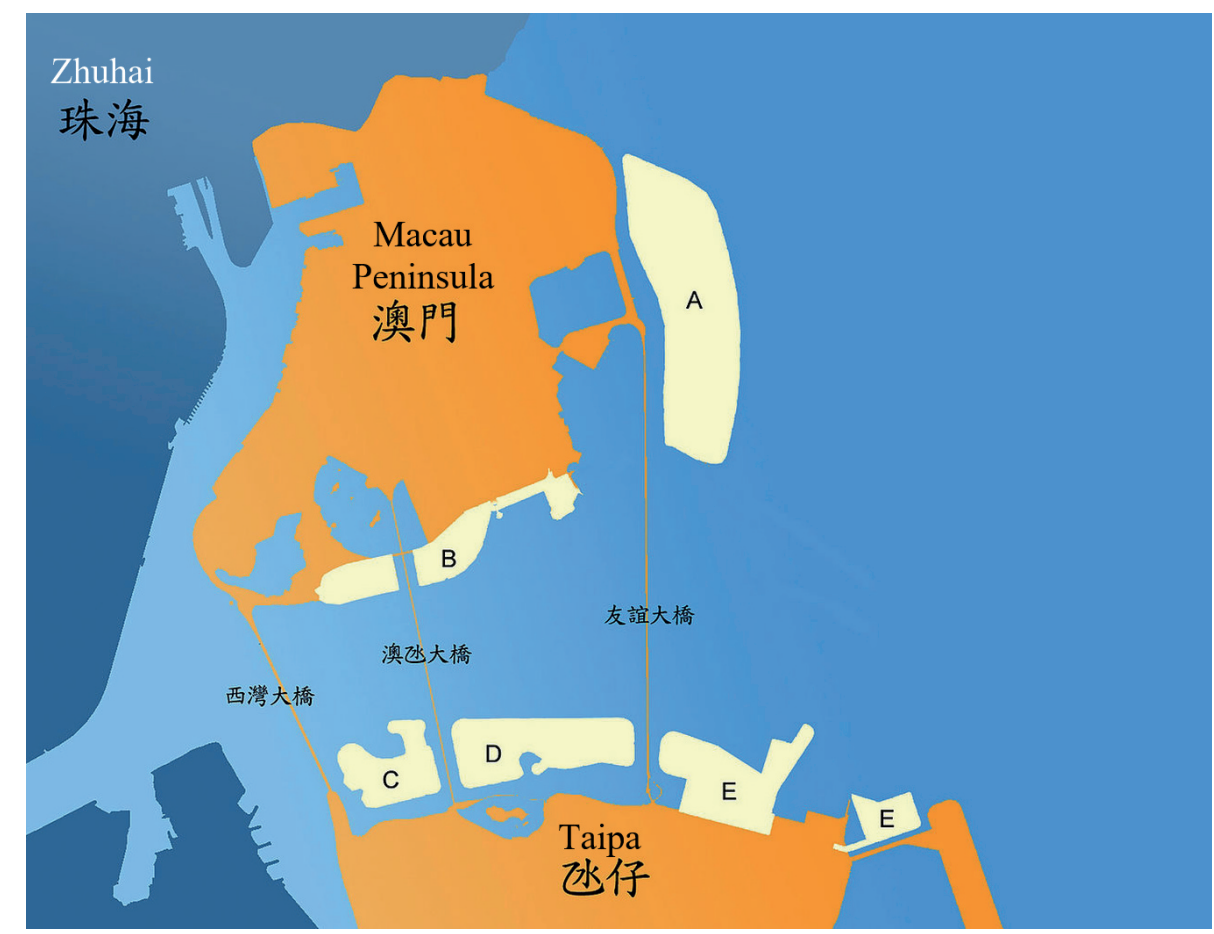

Figure 6: Five new urban zones A, B, C, D and E in the future (C) Macau Government, 2009, http://ibs.gcs.gov.mo/files/image b/20091130/0730112009.jpg) 
According to the government's master plan, Urban Zone A, the largest of the five, will be used for public housing, community recreation, and culture. It is expected to provide housing for around 57,000 people in around 19,000 housing units. To the east of Urban Zone A will be an artificial island, built for the Hong Kong-Zhuhai-Macau Bridge, which is currently under construction. Urban Zone B will mainly be used for administrative offices, with priority given to judicial services and tourism. There will also be a promenade area with gardens by the sea, addressing the wider island city tendency for a lack of sea access (e.g., Swaminathan, 2014). Part of Urban Zone B will be reserved for housing and shopping. It will provide housing for around 6,000 people in around 2,000 housing units. It has been suggested that Urban Zone B should "harmonise with Macao's world heritage landscape and give continuity to the city centre function" (Macauhub, 2015). Urban Zones C, D, and E are expected to house 67,000 people in around 22,000 housing units. These three zones are designed as low-carbon pilot areas. The coast along the three zones "will be designated as a green corridor," where citizens and tourists can be in contact with the water and enjoy leisure activities (Lages, 2015; Macauhub, 2015). Such urban design utilises the questionable benefits of island spatiality for showcasing urban sustainability (Grydehøj \& Kelman, 2016).

This use of reclaimed land, particularly reclaimed islands, is part of a wider trend to use islands within cities as containers for functionally differentiated urban development (Grydehøj, 2014b, p. 187). Through the newly reclaimed urban zones, the government hopes to provide necessary space for Macau's long-term transportation planning, beautify the coast, and expand the overall urban space. This urban planning strategy seeks to break through the constraints that limited land resources place on Macau's social and economic development. The potential for even further urban expansion in the future has been facilitated through the Chinese state's granting of $85 \mathrm{~km}^{2}$ of marine territory to Macau in December 2015 (Macao Government Information Bureau, 2015).

\section{Conclusion}

Specific geographical, political, and socioeconomic contexts should be considered in investigations of urban fragmentation. Macau's island status has had a variety of important consequences for the city's urban fragmentation. This paper has provided an overview of Macau's historical development and analysed how the island spatiality-conditioned fragmentation of Macau's urban forms has influenced transport, the urban environment, and ultimately distribution of urban qualities and functions.

Because Macau Peninsula was once a small, hilly island that gradually expanded and connected to mainland China as a peninsula, the city's growth occurred in distinct and geographically contingent phases (i.e., 1557-1846, 1846-1912, 1912-1957, and 1957-present). This has resulted in the formation of four small urban fragments $\left(<3 \mathrm{~km}^{2}\right)$. Urban Fragment 1 reflects the urban landscape of late-Medieval Portugal as the area was confined by historic city walls against maritime incursion during 1557-1846. Urban Fragment 2 was formed when roads were designed to radiate from the military centre out towards the coast during 1846-1912, reflecting mid-19th century European urban design. Urban Fragments 3-4 were formed by various phases of coastal land reclamation, reflecting modern urban design since 1912. Macau's historically contingent growth has led to the development of highly distinct urban fragments, which has in turn led to spatial inequalities in environmental health. Macau's history of coastal land reclamation cannot be separated from its urban fragmentation. Island cities often densify and expand in fits and starts through piecemeal land reclamation, resulting in spatiotemporal divisions within the city, which abidingly condition future development.

The construction of five new urban fragments (increasing Macau's land area by $12 \%$ ) is designed to provide additional urban space to improve residents' quality of life but it also represents a continuation of a centuries-long process of island city morphological transformation. This is especially relevant in light of Macau's increasing connectivity to the wider Pearl River Delta 
megacity region, particularly in the form of the Hong Kong-Zhuhai-Macau Bridge. How will Macau's new urban zones interact with existing and emerging urban space in and beyond the city?

More generally, this paper has illustrated the necessity of an urban island studies perspective on Chinese coastal cities, which may defy western understandings of urbanisation processes precisely because of their island and archipelago geographies. Even the Pearl River Delta megacity region, at the vanguard of today's trend for explosive and connective urbanism, is being moulded by types and scales of deep-rooted spatiotemporal factors that are foreign to North American and European experience.

\section{Acknowledgments}

This study was supported by the Faculty Research Grant in Macau University of Science and Technology (FRG-17-021-MSB).

\section{References}

Baldacchino, G. \& Pleijel, C. (2010). European islands, development and the cohesion policy: a case study of Kökar, Åland Islands. Island Studies Journal, 5(1), 89-110.

Baldacchino, G. (2007). Fixed links and the engagement of islandness: reviewing the impact of the Confederation Bridge. Canadian Geographer, 51(3), 323-336. https://doi.org/10.1111/j.1541-0064.2007.00181.x

Bie, J., Jong, M.D., \& Derudder, B. (2015). Greater Pearl River Delta: historical evolution towards a global city-region. Journal of Urban Technology, 22(2), 103-123. https://doi.org/10.1080/10630732.2014.971575

Bremner, L. (2017). Observations on the concept of the aquapelago occasioned by researching the Maldives. Shima, 11(1), 18-29. https://doi.org/10.21463/shima.11.1.05

Brophy, J.E. (2017). Reiterating the boundary: community discourse in light of proposed technological change on Vinalhaven Island, Maine, USA. Island Studies Journal, 12(1), 187-206. https://doi.org/10.24043/isj.12

Carsjens, G.J., \& van Lier, H.N. (2002). Fragmentation and land-use planning: an introduction. Landscape and Urban Planning, 58(2-4), 79-82. https://doi.org/10.1016/S0169-2046(01)00210-9

Chen, J., Chang, K.T., Karacsonyi, D., \& Zhang, X. (2014). Comparing urban land expansion and its driving factors in Shenzhen and Dongguan, China. Habitat International, 43, 61-71. https://doi.org/10.1016/j.habitatint.2014.01.004

DSEC (2016). 2016 Macao in figures. Statistical Information System of Macao. Retrieved from http://www.dsec.gov.mo/CMSPages/e mn indicator.aspx

Gao, J., Wei, Y.D., Chen, W., \& Chen, J. (2014). Economic transition and urban land expansion in provincial China. Habitat International, 44, 461-473. https://doi.org/10.1016/j.habitatint.2014.09.002

Garrett, R.J. (2010). The defences of Macau: forts, ships and weapons over 450 years. Hong Kong: Hong Kong University Press.https://doi.org/10.5790/hongkong/9789622099937.001.0001

Gillis, J. (2004). Islands of the mind: how the human imagination created the Atlantic world. Houndmills: Palgrave Macmillan.

Graham, S. (2011). Cities under siege: the new military urbanism. London \& New York: Verso.

Graham, S. \& Marvin, S. (2001). Splintering urbanism: networked infrastructures, technological mobilities and the urban condition. London: Routledge.https://doi.org/10.4324/9780203452202

Grydehøj, A. \& Kelman, I. (2016). Island smart eco-cities: innovation, secessionary enclaves, and the selling of sustainability. Urban Island Studies, 2, 1-24. https://doi.org/10.20958/uis.2016.1

Grydehøj, A. (2015a). Island city formation and urban island studies. Area, 47(4), 429-435. https://doi.org/10.1111/area.12207 
Grydehøj, A. (2015b). Making ground, losing space: land reclamation and urban public space in island cities. Urban Island Studies, 1, 96-117.https://doi.org/10.20958/uis.2015.6

Grydehøj, A. (2014a). Constructing a centre on the periphery: urbanization and urban design in the island city of Nuuk, Greenland. Island Studies Journal, 9(2), 205-222.

Grydehøj, A. (2014b). Understanding island cities. Island Studies Journal, 9(2), 183-190.

Guillén-Nuñez, C. (2001). Macau's rich heritage and cultural diversity. Macau Focus, 1(3), 7-16.

Harvey, D. (2001). Spaces of capital: towards a critical geography. New York: Routledge.

Hayward, P. (2016). Towards an expanded concept of island studies. Shima, 10(1), 1-7. https://doi.org/10.21463/shima.10.1.03

Hayward, P., \& Fleury, C. (2016). Absolute waterfrontage: road networked artificial islands and finger island canal estates on Australia's Gold Coast. Urban Island Studies, 2, 25-49.

https://doi.org/10.20958/uis.2016.2

He, S., \& Qian, J. (2016). From an emerging market to a multifaceted urban society: urban China studies. Urban Studies, 54(4), 827-846.https://doi.org/10.1177/0042098016675826

Hong, G. (2017). Locating Zhuhai between land and sea: a relational production of Zhuhai, China, as an island city. Island Studies Journal, 12(2). https://doi.org/10.24043/isj.16

Johnson, H. \& Kuwahara, S. (2016). Sakurajima: maintaining an island essence. Shima, 10(1), 48-66. https://doi.org/10.21463/shima.10.1.07

Kuang, W., Chi, W., Lu, D., \& Dou, Y. (2014). A comparative analysis of megacity expansions in China and the U.S.: patterns, rates and driving forces. Landscape and Urban Planning, 132, 121-135. https://doi.org/10.1016/j.landurbplan.2014.08.015

Lages, A. (2015). Macau land reclamation to be done in the next 5 years. Delta Bridge. Retrieved from http://deltabridges.com/macau/business/news/macau-land-reclamation-be-done-next-5-years

Leung, A., Tanko, M., Burke, M., \& Shui, C.S. (2017). Bridges, tunnels, and ferries: connectivity, transport, and the future of Hong Kong's outlying islands. Island Studies Journal, 12(2). https://doi.org/10.24043/isj.24

Li, S. (2016). The transformation of island city politics: the case of Macau. Island Studies Journal, 11(2), 521-536.

Li, X., Zhou, W., \& Ouyang, Z. (2013). Forty years of urban expansion in Beijing: what is the relative importance of physical, socioeconomic, and neighborhood factors? Applied Geography, 38, 1-10. https://doi.org/10.1016/j.apgeog.2012.11.004

Lin, G.C.S. (2001). Metropolitan development in a transitional socialist economy: spatial restructuring in the Pearl River Delta, China. Urban Studies, 38(3), 383-406. https://doi.org/10.1080/00420980120027429

Macao Government Information Bureau (2015). Macao to administrate 85 square kilometres of waters. Retrieved from http://www.gcs.gov.mo/showNews.php?PageLang=E\&DataUcn=95418

Macauhub (2015). Macao builds a new frontier with ambitious reclamation. Retrieved from http://www.macauhub.com.mo/en/2015/04/24/macao-builds-a-new-frontier-withambitious-reclamation/

Mendas, Z. (2016). Historico-economic traces in the former island cities of Zadar and Trogir. Shima, 10(1), 85-110. https://doi.org/10.21463/shima.10.1.09

Miyahara, S., Uda, T., \& Serizawa, M. (2014). Prediction of formation of land-tied islands. Proceedings of 34th Conference on Coastal Engineering, Seoul, Korea, 34. https://doi.org/10.9753/icce.v34.sediment.7

Raadik Cottrell, J. (2017). Island community: identity formulation via acceptance through the environment in Saaremaa, Estonia. Island Studies Journal, 12(1), 169-186. https://doi.org/10.24043/isj.11

Riley, C. (2014). Macau's gambling industry dwarfs Vegas. CNN Money. Retrieved from http://money.cnn.com/2014/01/06/news/macau-casino-gambling/ 
Schneider, A., Seto, K.C., \& Webster, D.R. (2005). Urban growth in Chengdu, Western China: application of remote sensing to assess planning and policy outcomes. Environment and Planning B: Planning and Design, 32(3), 323-345.https://doi.org/10.1068/b31142

Sheng, N., \& Tang, U.W. (2015). Spatial techniques to visualize acoustic comfort along cultural and heritage routes for a world heritage city. Sustainability, 7, 10264-10280. https://doi.org/10.3390/su70810264

Sheng, N., \& Tang, U.W. (2013). Risk assessment of traffic-related air pollution in a world heritage city. International Journal of Environmental Science and Technology, 10, 11-18. https://doi.org/10.1007/s13762-012-0030-1

Sheng, N., \& Tang, U.W. (2011). Spatial analysis of urban form and pedestrian exposure to traffic noise. International Journal of Environmental Research and Public Health, 8, 1977-1990. https://doi.org/10.3390/ijerph8061977

Simpson, T. (2014). Macau metropolis and mental life: interior urbanism and the Chinese imaginary. International Journal of Urban and Regional Research, 38(3), 823-842. https://doi.org/10.1111/1468-2427.12139

Steyn, G. (2015). The impacts of islandness on the urbanism and architecture of Mombasa. Urban Island Studies, 1, 55-80. https://doi.org/10.20958/uis.2015.4

$\mathrm{Su}, \mathrm{P}$. (2017). The floating community of Muslims in the island city of Guangzhou. Island Studies Journal, 12(2). https://doi.org/10.24043/isj.18

Swaminathan, R. (2014). The epistemology of a sea view: mindscapes of space, power and value in Mumbai. Island Studies Journal, 9(2), 277-292.

Tan, M., Li, X., Xie, E.H., \& Lu, C. (2005). Urban land expansion and arable land loss in China: a case study of Beijing-Tianjin-Hebei region. Land Use Policy, 22(3), 187-196. https://doi.org/10.1016/j.landusepol.2004.03.003

Tang, U.W., \& Sheng, N. (2009). Macao. Cities, 26(4), 220-231. https://doi.org/10.1016/j.cities.2009.02.005

Tang, U.W., \& Wang, Z.S. (2007). Influences of urban forms on traffic-induced noise and air pollution: results from a modelling system. Environmental Modelling and Software, 22(12), 1750-1764. https://doi.org/10.1016/j.envsoft.2007.02.003

Time Out Hong Kong (2016). The Pearl River Delta megacity. Time Out Hong Kong, 17 May. Retrieved from: https://www.timeout.com/hong-kong/en-hongkong/the-pearl-riverdelta-megacity-051716

UNESCO (2005). World Heritage List: Historic Centre of Macao. Retrieved from: http://whc.unesco.org/en/list/1110

Van Mead, R. (2015). China's Pearl River Delta overtakes Tokyo as world's largest megacity. The Guardian, 28 January. Retrieved from: https://www.theguardian.com/cities/2015/jan/28/china-pearl-river-delta-overtake-tokyoworld-largest-megacity-urban-area

Vong, C.S. (2009). Geografia de Macau. Hong Kong: Joint Publishing.

Wei, Y., \& Zhang, Z. (2012). Assessing the fragmentation of construction land in urban areas: an index method and case study in Shunde, China. Land Use Policy, 29(2), 417-428. https://doi.org/10.1016/j.landusepol.2011.08.006

Yao, S. \& Liu, T. (1995). The evolution of urban spatial structure in the open area of southeastern coastal China. Urban Geography, 16(7), 561-576. https://doi.org/10.2747/0272$\underline{3638.16 .7 .561}$

You, H. (2016a). Quantifying megacity growth in response to economic transition: a case of Shanghai, China. Habitat International, 53, 115-122. https://doi.org/10.1016/j.habitatint.2015.11.001

You, H. (2016b). Quantifying urban fragmentation under economic transition in Shanghai city, China. Sustainability, 8(1), 21. https://doi.org/10.3390/su8010021 
Yu, X.J., \& Ng, C.N. (2007). Spatial and temporal dynamics of urban sprawl along two urban-rural transects: a case study of Guangzhou, China. Landscape and Urban Planning, 79(1), 96-109. https://doi.org/10.1016/j.landurbplan.2006.03.008

Yue, W., Liu, Y., \& Fan, P. (2013). Measuring urban sprawl and its drivers in large Chinese cities: the case of Hangzhou. Land Use Policy, 31, 358-370. https://doi.org/10.1016/j.landusepol.2012.07.018

Zadori, I. (2016). Cultural aspects of sustainability challenges of island-like territories: case study of Macau, China. Ecocycles, 1(2), 35-45. 